\title{
MALAT1 long non-coding RNA is overexpressed in multiple myeloma and may serve as a marker to predict disease progression
}

Shih-Feng Cho ${ }^{1,2}$, Yuli Christine Chang ${ }^{3}$, Chao-Sung Chang ${ }^{2,4}$, Sheng-Fung Lin ${ }^{2,5}$, Yi-Chang Liu ${ }^{2,5}$, Hui-Hua Hsiao ${ }^{2,5}$, Jan-Gowth Chang ${ }^{6,7,8^{*}}$ and Ta-Chih Liu ${ }^{1,2^{*}}$

\begin{abstract}
Background: The pathogenesis of multiple myeloma involves complex genetic and epigenetic events. This study aimed to investigate the role and clinical relevance of the long non-coding RNA (IncRNA), metastasis-associated lung adenocarcinoma transcript 1 (MALAT1) in multiple myeloma.

Methods: Bone marrow mononuclear cells were collected for analysis. The samples of multiple myeloma were taken from 45 patients at diagnosis, 61 post-treatment, and 18 who relapsed or had progression. Control samples were collected from 20 healthy individuals. Real-time quantitative reverse transcription polymerase chain reactions were performed to evaluate the expression of MALAT1. The clinical relevance of MALAT1 expression was also explored.

Results: MALAT1 was overexpressed in the newly diagnosed patients compared with post-treatment patients (mean $\Delta \mathrm{C}_{\mathrm{T}}$ : $-5.54 \pm 0.16$ vs. $-3.84 \pm 0.09,3.25$-fold change; $\mathrm{p}<0.001$ ) and healthy individuals (mean $\Delta \mathrm{C}_{\mathrm{T}}:-5.54 \pm 0.16$ vs. $-3.95 \pm 0.21,3.01$-fold change; $p<0.001$ ). The expression of MALAT1 strongly correlated with disease status, and the magnitude of change in MALAT1 post-treatment had prognostic relevance. The patients with early progression had a significantly smaller change in MALAT1 after treatment (mean $\Delta C_{T}$ change: $1.26 \pm 1.06$ vs. $2.09 \pm 0.79, p=0.011$ ). A cut-off value of the change in MALAT1 ( $\triangle C_{T}$ change: 1.5) was obtained, and the patients with a greater decrease in MALAT1 (difference in $\Delta \mathrm{C}_{\mathrm{T}}>1.5$ ) had significantly longer progression-free survival compared with the patients with a smaller MALAT1 change (24 months vs. 11 months; $p=0.001$ ). For the post-treatment patients, the risk of early progression could be predicted using this cut-off value.
\end{abstract}

Conclusions: MALAT1 was overexpressed in patients with myeloma and may play a role in its pathogenesis. In addition, MALAT1 may serve as a molecular predictor of early progression.

Keywords: Multiple myeloma, Long non-coding RNA, Metastasis-associated lung adenocarcinoma transcript 1 (MALAT1)

\section{Background}

Multiple myeloma is a hematological malignancy characterized by abnormal proliferation of monoclonal plasma cells in bone marrow leading to various end-organ damage including anemia, hypercalcemia, renal insufficiency and osteolytic bone disease [1]. The development of multiple myeloma is thought to result from monoclonal

\footnotetext{
*Correspondence: d6781@mail.cmuh.org.tw; d730093@cc.kmu.edu.tw ${ }^{6}$ Epigenome Research Center, China Medical University Hospital, No. 2, Yuh-Der Road, Taichung 404, Taiwan

${ }^{1}$ Graduate Institute of Clinical Medicine, College of Medicine, Kaohsiung Medical University, No.100, Shih-Chuan 1st Road, Kaohsiung 807, Taiwan Full list of author information is available at the end of the article
}

gammopathy of undetermined clinical significance [2,3]. With the progression from monoclonal gammopathy of undetermined clinical significance to myeloma, several complex genetic events are involved including cytogenetic abnormalities, primary or secondary chromosomal translocation, and activation of oncogenes. These oncogenetic events include dysregulation of the cyclin $D$ gene, mutation of KRAS or NRAS, and constitutively activated nuclear factor $\kappa \mathrm{B}(\mathrm{NF} \kappa \mathrm{B})$ pathway [4-7]. In addition, the bone marrow microenvironment has also been reported to play an important role in the pathogenesis of this disease [8-10].

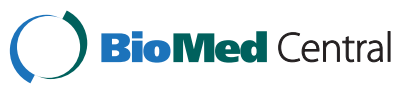

(c) 2014 Cho et al.; licensee BioMed Central Ltd. This is an Open Access article distributed under the terms of the Creative Commons Attribution License (http://creativecommons.org/licenses/by/4.0), which permits unrestricted use, distribution, and reproduction in any medium, provided the original work is properly credited. The Creative Commons Public Domain Dedication waiver (http://creativecommons.org/publicdomain/zero/1.0/) applies to the data made available in this article, unless otherwise stated. 
The human genome project revealed that at least $90 \%$ of the human genome is actively transcribed to RNA, but less than $2 \%$ of RNA encodes proteins [11,12]. Non-coding RNAs (ncRNAs) are a class of RNA with little or no capacity for protein synthesis that includes small ncRNAs and long ncRNAs (lncRNAs), which have a length of more than 200 nucleotides. The lncRNAs have been highly conserved throughout mammalian evolution including in humans, and they have been shown to be aberrantly expressed in cancer tissue and to be involved in oncogenic or tumor suppressive processes [13].

Metastasis-associated lung adenocarcinoma transcript 1 (MALAT1) is one of the few biologically well-studied lncRNAs, and is located on chromosome 11 (11q13.1). This lncRNA is highly conserved in mammals and is more than 8000 nucleotides in length [14-16]. MALAT1 has been shown to expressed in numerous tissues including the central nervous, endocrine, immune, reproductive and lymphoid systems $[17,18]$. With respect to its function, MALAT1 is localized to nuclear speckles and has been associated with regulation of gene expressions $[19,20]$. In addition, MALAT1 may play a role in the regulation of alternative splicing and cell cycle [21-23]. In terms of its association with cancer, MALAT1 has been shown to be oncogenic and to be overexpressed in several solid tumors including lung, colorectal, bladder and laryngeal cancers [24-27].

The association between lncRNAs and multiple myeloma remains undetermined, and related studies are lacking. It has been reported that deregulation of the cell cycle is an important event during carcinogenesis, and that this event is also associated with MALAT1 [23]. $M A L A T 1$ has also been reported to be expressed broadly in human tissues including lymphoid tissues, bone marrow and B lymphocytes [28,29]. Taken together, we hypothesized that MALAT1 may play a role in multiple myeloma. Therefore, the aim of the present study was to evaluate the expression of MALAT1 in bone marrow mononuclear cells from patients with multiple myeloma and with different disease status and healthy individuals.

\section{Methods}

\section{Multiple myeloma patients and samples}

The study cohort included adult patients (aged 20 years and older) with multiple myeloma diagnosed at Kaohsiung Medical University Hospital from 2007 to 2012 who were free from other coexisting malignant diseases. The diagnosis of multiple myeloma was confirmed by bone marrow analysis which revealed a monoclonal plasma cell count over $10 \%$ by definition and related laboratory tests. The patients of extramedullary myeloma were not enrolled to this study. The diagnostic criteria, disease status and response to treatment were based on the criteria of the International Myeloma Working Group [17-19]. Forty-five samples were collected from newly diagnosed patients (29 males, 16 females; median age 62.3 years, range 49 to 79 years) with different subtypes (IgG: 21, IgA: 13, light chain: 11) and clinical stages (Durie-Salmon stage 1: 1, stage 2: 6, stage 3: 38 or international staging system stage $1: 7$, stage 2 : 17 , stage 3: 21). In addition, 61 samples were collected from patients after myeloma treatment, and 18 samples from patients who had experienced disease progression or relapse. The disease status of the post-treatment patients was mainly a complete response $(\mathrm{CR})$ and very good partial response (VGPR) based on the criteria of International Myeloma Working Group. In addition, the percentage of plasma cells in the patients achieving VGPR or CR after treatment was less than $5 \%$.

We also enrolled 20 healthy and genetically unrelated Taiwanese volunteers (healthy individuals) as the control group. These healthy individuals had undergone bone marrow analysis to investigate cytopenia that had been noted in blood tests, but whose bone marrow examinations revealed no abnormalities. All patients and healthy individuals signed informed consent forms after the study had been thoroughly explained.

The research protocol was created in accordance with the Declaration of Helsinki, and it was reviewed, approved and registered by the Ethics Committee of Kaohsiung Medical University Hospital (KMUHIRB-2012-01-08(II)).

\section{RNA extraction and reverse transcription}

Bone marrow mononuclear cells were isolated for this study. First, the bone marrow samples were collected in tubes containing ethylenediaminetetraacetic acid (EDTA), preserved at $4^{\circ} \mathrm{C}$ and processed within 4 hours of collection. The bone marrow samples were then centrifuged at $12,000 \times \mathrm{g}$ for 15 minutes, after which ammonium chloride lysis buffer $(10 \mathrm{mM} \mathrm{NH} 4 \mathrm{Cl}, 10 \mathrm{mM}$ KHCO3, $0.1 \mathrm{mM}$ EDTA) was used to clear the red blood cells and effectively isolate the fraction of mononuclear cells.

The isolated bone marrow samples were stored at $-80^{\circ} \mathrm{C}$ until RNA extraction. Isolation of RNA from $200 \mu \mathrm{L}$ of cell suspension was carried out using the TRIzol protocol (Invitrogen). The extracted RNA was then treated with DNase (Promega) and the concentration was determined by spectrophotometric OD260 measurement. The integrity of the RNA was examined by $1.2 \%$ RNA denaturing agarose gel electrophoresis.

Reverse transcription was performed to generate complementary DNA in a final volume of $20 \mu \mathrm{L}$, containing $2 \mu \mathrm{g}$ RNA, 25X dNTP mix (100 mM), 10X random primer (0.5 $\mu \mathrm{M})$, RNase inhibiter, reverse transcriptase, reverse transcriptase buffer (10X) and diethylpyrocarbonate (DEPC)treated water. The procedure was performed according to the manufacturer's protocol (Applied Biosystems). 
Real-time quantitative reverse transcription polymerase chain reaction (RT-PCR) analysis of MALAT1 expression

Real-time quantitative RT-PCR was performed in a final volume of $10 \mu \mathrm{L}$ containing $1 \mu \mathrm{L}$ of RT product, $0.6 \mu \mathrm{L}$ of primer (Roche), $1.2 \mu \mathrm{L}$ of probe (Roche, cat. no. 04688945001), $2.2 \mu \mathrm{L}$ of DEPC $\mathrm{H}_{2} \mathrm{O}$ and $5 \mu \mathrm{L}$ of qPCR Master Mix (2X) (KAPA Biosystem, KK 4600). Analysis of the human glyceraldehyde-3-phosphate dehydrogenase $(G A P D H)$ gene was used as the internal control.

The primer sequences of MALAT1 were as follows: forward, 5'-GACCCTTCACCCCTCACC-3'; reverse, 5'-TTATGGATCATGCCCACAAG-3', and the primer sequences of $G A P D H$ were as follows: forward, 5'AAAGTCCGCCATTTTGCCACT-3'; and reverse, 5'-CCAAATCGTTAGCGCTCCTT-3'.

Real-time quantitative RT-PCR was performed in a LightCycler 480 Real-Time PCR System (Roche). The PCR cycling program consisted of incubation for enzyme activation at $95^{\circ} \mathrm{C}$ for 10 minutes, followed by melting at $95^{\circ} \mathrm{C}$ for 10 seconds, annealing at $60^{\circ} \mathrm{C}$ for 30 seconds, and then extension at $72^{\circ} \mathrm{C}$ for 1 second, for a total of 50 cycles.

The expression levels of MALAT1 were normalized to the internal control GAPDH reference to obtain the relative threshold cycle $\left(\Delta \mathrm{C}_{\mathrm{T}}\right)$. The relative expression levels were calculated by the comparative $C_{T}\left(\Delta \Delta C_{T}\right)$ method, and relative expression folds $\left(2^{-\Delta \Delta C T}\right)$ were calculated.

\section{Statistical analysis}

The independent two samples t-test was used to compare the expression levels of MALAT1 in the different subgroups. The frequency between each categorical variable was compared by the chi-square test ( $\mathrm{x} 2$ test), with Yates correction or Fisher's exact test. Analysis of correlation was performed using Pearson correlations or Spearman correlation coefficients. Receiver operating characteristic (ROC) analysis was used to evaluate the cut-off value. Survival curves were plotted using the Kaplan-Meier method and compared using the log-rank test. Relative risk analysis was performed by calculating the odds ratio (OR) and 95\% confidence interval (CI) by Cox regression analysis.

All statistical analyses were based on two-sided hypothesis tests with a significance level of $\mathrm{p}<0.05$. The analyses were performed using SPSS version 17.0 (SPSS, Chicago, IL, USA).

\section{Results}

Correlation of MALAT1 expression with disease status in multiple myeloma

The expression of MALAT1 was significantly higher in the patients at diagnosis compared with the patients post-treatment (mean $\Delta \mathrm{C}_{\mathrm{T}}:-5.54 \pm 0.16$ vs. $-3.84 \pm 0.09$, 3.25-fold change; $\mathrm{p}<0.001)$ or the healthy individuals (mean $\Delta \mathrm{C}_{\mathrm{T}}$ : $-5.54 \pm 0.16$ vs. $-3.95 \pm 0.21,3.01$-fold change; $\mathrm{p}<0.001$ ) (Table 1). This suggests that MALAT1 may be deregulated and overexpressed in patients with multiple myeloma.

The association of MALAT1 expression pattern with disease status was further analyzed. The expression of MALAT1 was found to be significantly decreased in the post-treatment patients to a level that was similar to that of the healthy individuals (mean $\Delta \mathrm{C}_{\mathrm{T}}$ : $-3.84 \pm 0.09$ vs. $-3.95 \pm 0.21, p=0.614$ ). In addition, in the patients in whom the disease had progressed or relapsed, the expression of MALAT1 was significantly increased compared with the post-treatment patients (mean $\Delta \mathrm{C}_{\mathrm{T}}:-4.92 \pm 0.23$ vs. $-3.84 \pm 0.09,1.89$-fold change; $\mathrm{p}<0.001$ ) (Table 1 ). For the patients who underwent multiple bone marrow examinations during treatment and follow-up, the expression of MALAT1 changed dynamically and was correlated with disease status (Figure 1).

\section{Association between MALAT1 expression and clinical outcome}

The clinical relevance of $M A L A T 1$ was analyzed. The expressions of MALAT1 in the 45 newly diagnosed patients with different clinical characteristics were listed in Additional file 1: Table S1. We noticed that the expression of MALAT1 was not associated with the percentage of plasma cells in the bone marrow $(\mathrm{r}=-0.037$, $\mathrm{p}=0.808$ ) (Additional file 2: Table S2). With regards to the association between MALAT1 expression and prognosis,

Table 1 Expression of MALAT1 in patients with multiple myeloma and healthy individuals

\begin{tabular}{|c|c|c|c|}
\hline Population & No. & $\begin{array}{l}\text { Expression of MALAT1 } \\
\left(\text { Mean } \Delta \mathrm{C}_{\mathrm{T}}\right)\end{array}$ & \\
\hline Newly diagnosed & 45 & $-5.54 \pm 0.16$ & \\
\hline Post-treatment & 61 & $-3.84 \pm 0.09$ & \\
\hline Relapse or progression & 18 & $-4.92 \pm 0.23$ & \\
\hline \multirow[t]{2}{*}{ Healthy individuals } & 20 & $-3.95 \pm 0.21$ & \\
\hline & $\Delta \Delta C_{T}$ & Fold change & $P$ value \\
\hline $\begin{array}{l}\text { Newly diagnosed vs. } \\
\text { Post-treatment }\end{array}$ & -1.70 & 3.25 & $<0.001$ \\
\hline $\begin{array}{l}\text { Newly diagnosed vs. } \\
\text { Healthy individuals }\end{array}$ & -1.59 & 3.01 & $<0.001$ \\
\hline $\begin{array}{l}\text { Relapse or progression vs. } \\
\text { Post-treatment }\end{array}$ & -0.92 & 1.89 & $<0.001$ \\
\hline $\begin{array}{l}\text { Post-treatment vs. } \\
\text { Healthy individuals }\end{array}$ & 0.11 & 1.08 & 0.614 \\
\hline
\end{tabular}

The 61 post-treatment samples were composed of 58 samples collected in disease status of VGPR or CR from 42 patients. The percentages of plasma cells were all less than $5 \%$.

The 3 samples collected at a disease status of partial response came from

3 patients.

Note:

$\triangle \mathrm{C}_{\mathrm{T}}=\mathrm{C}_{\mathrm{T}}($ MALAT1 - GAPDH)

Increased expression (fold change) was calculated as $2^{-\Delta \Delta C T}$. 


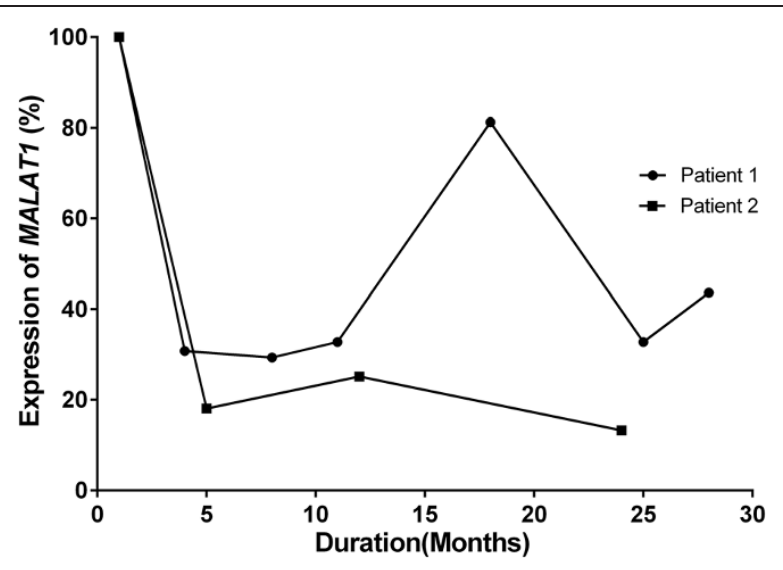

Figure 1 Expression of MALAT1 during treatment and follow-up in two representative patients. The first patient (Patient 1) had a high expression of MALAT1 initially, which then decreased after successful induction chemotherapy and autologous peripheral blood stem cell transplantation, 9 months after the time of diagnosis. At 18 months, disease relapse was accompanied by an increase in MALAT1 expression. After salvage treatment, the disease was controlled and the expression of MALAT1 decreased. Eventually, the disease progressed and the expression of MALAT1 increased. The second patient (Patient 2) received induction chemotherapy followed by peripheral blood stem cell transplantation. The expression of MALAT1 decreased markedly after the treatment achieved complete remission. The disease status remained in remission during the follow-up period and was accompanied by a low expression of MALATT.

the results showed that the initial higher MALAT1 expression level (Cut-off value: $\Delta C_{\mathrm{T}}=-5.30$ ) determined by $\mathrm{ROC}$ analysis was not associated with inferior prognosis including progression-free survival (PFS) (median PFS: $21.0 \pm 9.9$ vs. $15.0 \pm 6.0$ months, $\mathrm{p}=0.390$ ) or overall survival (OS) (median OS: Not reached; mean OS: $31.9 \pm 4.3$ vs. $37.8 \pm 3.6$ months, $\mathrm{p}=0.172$ ) (Additional file 3: Figure S1). However, we hypothesized the magnitude of the change (decrease) after myelomarelated therapy may have been related to the degree of treatment response and prognosis, because the expression of MALAT1 changed after treatment.

Among the 45 patients, 36 (including 21 men) with a mean age of 61.3 years received bone marrow examinations at least twice including at diagnosis and after treatment, and hence the expression of MALAT1 was available for further analysis. The median PFS of these 36 patients was 18 months (95\% CI 8.95-25.35), and we used this median PFS as a cut-off value to divide the patients into two groups of early (PFS $\leq 18$ months) or late (PFS $>18$ months) progression, with 18 patients in each group. We found that the only parameter which showed a significant difference between these two groups was the magnitude of MALAT1 change after treatment. The patients with early progression had a significantly smaller magnitude of MALAT1 change after treatment compared with the patients with late progression (mean difference of $\Delta \mathrm{C}_{\mathrm{T}}: 1.26 \pm 1.06 \mathrm{vs}$. $2.09 \pm 0.79 ; \mathrm{p}=0.011)($ Table 2$)$.

\section{Role of MALAT1 in predicting early progression}

The previous results showed that the magnitude of MALAT1 change (as quantified by the difference in $\Delta \mathrm{C}_{\mathrm{T}}$ ) was the only parameter associated with PFS. We then used ROC analysis and obtained a cut-off expression change value of 1.5 (post-treatment $\Delta C_{T}$ - pre-treatment $\Delta C_{T}$; approximately a 2.8 -fold change) with an estimated area under the ROC curve of $0.79(\mathrm{p}=0.003)$. The proportion of patients with a lower MALAT1 change (difference in $\left.\Delta C_{\mathrm{T}} \leq 1.5\right)$ was significantly higher in those who displayed early progression $(n=13,72.2 \%)$ compared with those who displayed late progression $(\mathrm{n}=4,22.2 \% ; \mathrm{p}=0.007)$.

In terms of an association between clinical characteristics and magnitude of MALAT1 change, the patients with greater changes (difference in $\Delta \mathrm{C}_{\mathrm{T}}>1.5$ ) may have had a better treatment response (Additional file 4: Table S3). The PFS and OS rates were also analyzed using the cut-off value from ROC analysis. With a minimum follow-up period of 12 months (range: 12 to 48 months), the patients with a greater MALAT1 decrease (difference in $\Delta \mathrm{C}_{\mathrm{T}}>1.5$ ) had a significantly prolonged median PFS (24 months, range 11-48 months) compared with the patients with a smaller MALAT1 change (11 months, range: 6-21 months; $\mathrm{p}=0.001$ ). There was no significant difference in OS between the two groups (median OS: Not reached; mean OS: $39.2 \pm 3.6$ months, range: $12-48$ months vs. $32.8 \pm 4.2$ months, range: $12-48$ months; $\mathrm{p}=0.313$ ) (Figure 2).

Cox regression analysis was used to identify the relative risk of early progression, which revealed that autologous hematopoietic stem cell transplantation (Auto-HSCT) and the magnitude of MALAT1 change were significantly associated with the prognosis. For all post-treatment patients $(\mathrm{n}=36)$, those with a smaller MALAT1 change (difference in $\left.\Delta \mathrm{C}_{\mathrm{T}} \leq 1.5\right)$ had a significantly higher risk of early progression of disease (OR 4.89, 95\% CI 1.73-13.86; $\mathrm{p}=0.003$ ), while auto-HSCT reduced the risk of early progression (OR 0.22 , 95\% CI 0.05-0.97; $\mathrm{p}=0.046)$. For the post-treatment patients with a VGPR or CR $(\mathrm{n}=33)$, a smaller MALAT1 change (difference in $\Delta C_{T} \leq 1.5$ ) remained the single factor predictive of early progression of multiple myeloma (OR 4.38, 95\% CI 1.48-12.99; $\mathrm{p}=0.008$ ) (Table 3). Using the cut-off value to predict the patients who would show early progression (PFS $\leq 18$ months), the estimated accuracy was $75 \%$ with a sensitivity of $72.2 \%$, a specificity of $77.8 \%$, a positive predictive value of $76.5 \%$, and a negative predictive value of $73.7 \%$.

\section{Discussion}

In the current study, we demonstrated that MALAT1 was overexpressed in the patients with newly diagnosed 
Table 2 The clinical characteristics of patients with early (PFS $\leq 18$ months) or late (PFS $>18$ months) progression

\begin{tabular}{|c|c|c|c|c|}
\hline & $\begin{array}{l}\text { All patients } \\
(\mathrm{N}=36)\end{array}$ & $\begin{array}{c}\mathrm{PFS} \leq 18 \text { months } \\
\quad(\mathrm{N}=18)\end{array}$ & $\begin{array}{l}\text { PFS > } 18 \text { months } \\
\quad(\mathrm{N}=18)\end{array}$ & $P$ value \\
\hline Age (years, mean(SD)) & $61.3(8.3)$ & $61.9 \pm 7.8$ & $60.6 \pm 8.7$ & 0.633 \\
\hline Male, n (\%) & $21(58.3 \%)$ & $10(55.6 \%)$ & $11(61.1 \%)$ & 1.000 \\
\hline M protein & & & & 0.210 \\
\hline $\operatorname{lgG}, \mathrm{n}(\%)$ & $19(52.8 \%)$ & $7(38.9 \%)$ & $12(66.6 \%)$ & \\
\hline $\lg A, n(\%)$ & $10(27.8 \%)$ & 7(38.9\%) & $3(16.7 \%)$ & \\
\hline Light chain, n (\%) & $7(19.4 \%)$ & $4(22.2 \%)$ & $3(16.7 \%)$ & \\
\hline International staging system & & & & 0.881 \\
\hline Stage 1, n (\%) & $5(13.9 \%)$ & $2(11.1 \%)$ & $3(16.7 \%)$ & \\
\hline Stage 2, n (\%) & 12(33.3\%) & $6(33.3 \%)$ & $6(33.3 \%)$ & \\
\hline Stage 3, n (\%) & 19(52.8\%) & 10(55.6\%) & $9(50 \%)$ & \\
\hline Durie-Salmon stage & & & & 1.000 \\
\hline Stage 1, n (\%) & 0 & 0 & 0 & \\
\hline Stage 2, n (\%) & $5(13.9 \%)$ & $2(11.1 \%)$ & $3(16.7 \%)$ & \\
\hline Stage 3, n (\%) & $31(86.1 \%)$ & 16(88.9\%) & 15(83.3\%) & \\
\hline Percentage of plasma cell in bone marrow $(\%$, mean (SD)) & $50.8 \pm 25.3$ & $54.3 \pm 26.8$ & $47.3 \pm 23.8$ & 0.740 \\
\hline Anemia, n (\%) & $27(75 \%)$ & $14(77.8 \%)$ & $13(72.2 \%)$ & 1.000 \\
\hline Renal insufficiency, n (\%) & $9(25 \%)$ & $5(27.8 \%)$ & $4(22.2 \%)$ & 1.000 \\
\hline Hypercalcemia, n (\%) & 14(38.9\%) & $8(44.4 \%)$ & $6(33.3 \%)$ & 0.733 \\
\hline Bone disease, n (\%) & $25(69.4 \%)$ & $14(77.8 \%)$ & $11(61.1 \%)$ & 0.471 \\
\hline Cytogenetic abnormality, n (\%) & $7(19.4 \%)$ & $3(16.7 \%)$ & $4(22.2 \%)$ & 1.000 \\
\hline Bortezomib-containing induction Tx, n (\%) & $11(30.6 \%)$ & $4(22.2 \%)$ & $7(38.9 \%)$ & 0.471 \\
\hline Auto-HSCT in 1st fine Tx, $\mathrm{n}(\%)$ & $9(25 \%)$ & $2(11.1 \%)$ & $7(38.9 \%)$ & 0.121 \\
\hline \multicolumn{5}{|l|}{ Treatment response: } \\
\hline CR, n (\%) & $7(19.4 \%)$ & $1(5.6 \%)$ & $6(33.3 \%)$ & 0.088 \\
\hline VGPR, n (\%) & $26(72.2 \%)$ & $14(77.8 \%)$ & $12(66.7 \%)$ & 0.711 \\
\hline $\mathrm{PR}, \mathrm{n}(\%)$ & $3(8.3 \%)$ & $3(16.7 \%)$ & 0 & 0.229 \\
\hline Expression of MALAT1 at diagnosis (Mean $\Delta \mathrm{C}_{\mathrm{T}} \pm \mathrm{SD}$ ) & & $-5.52 \pm 1.15$ & $-5.77 \pm 0.89$ & 0.353 \\
\hline Magnitude of MALAT1 change after treatment (Difference in $\triangle C_{T}$ ) & & $1.26 \pm 1.06$ & $2.09 \pm 0.79$ & 0.011 \\
\hline
\end{tabular}

Difference in $\Delta \mathrm{C}_{\mathrm{T}}=\Delta \mathrm{C}_{\mathrm{T}}$ (Post-treatment - newly diagnosed).

Auto-HSCT, autologous hematopoietic stem cell transplantation; $C R$, complete response; VGPR, very good partial response; PFS, progression-free survival; Tx, treatment.

multiple myeloma. This finding indicates that MALAT1 may play a role in multiple myeloma.

The results of the present study are in contrast with the study by Isin et al., in which the expression of MALAT1 was found to be significantly lower in patients with multiple myeloma [30]. A possible explanation for this discrepancy may be due to different sample sources. Our study analyzed the expression of MALAT1 in bone marrow mononuclear cells rather than plasma samples, because the pathogenesis of myeloma is closely related to bone marrow. Another possible explanation for the higher expression of MALAT1 in the current study may be associated with the bone marrow microenvironment which supports the proliferation of myeloma cells. In addition, our analysis revealed that expression of MALAT1 in newly diagnosed myeloma patients is not associated with the total percentage of plasma cells in the bone marrow. This finding indicated that the expression of MALAT1 may be associated with interactions between myeloma cells and the bone marrow microenvironment. The detailed mechanism needs further studies to elucidate.

The current study also investigated the clinical relevance of MALAT1 in patients with multiple myeloma. We found that the expression of MALAT1 changed dynamically when stratified by disease status. In addition, the major clinical significance was the magnitude of change in expression after treatment rather than the initial expression. This finding is different from previous studies of solid tumors which have reported that a higher expression 


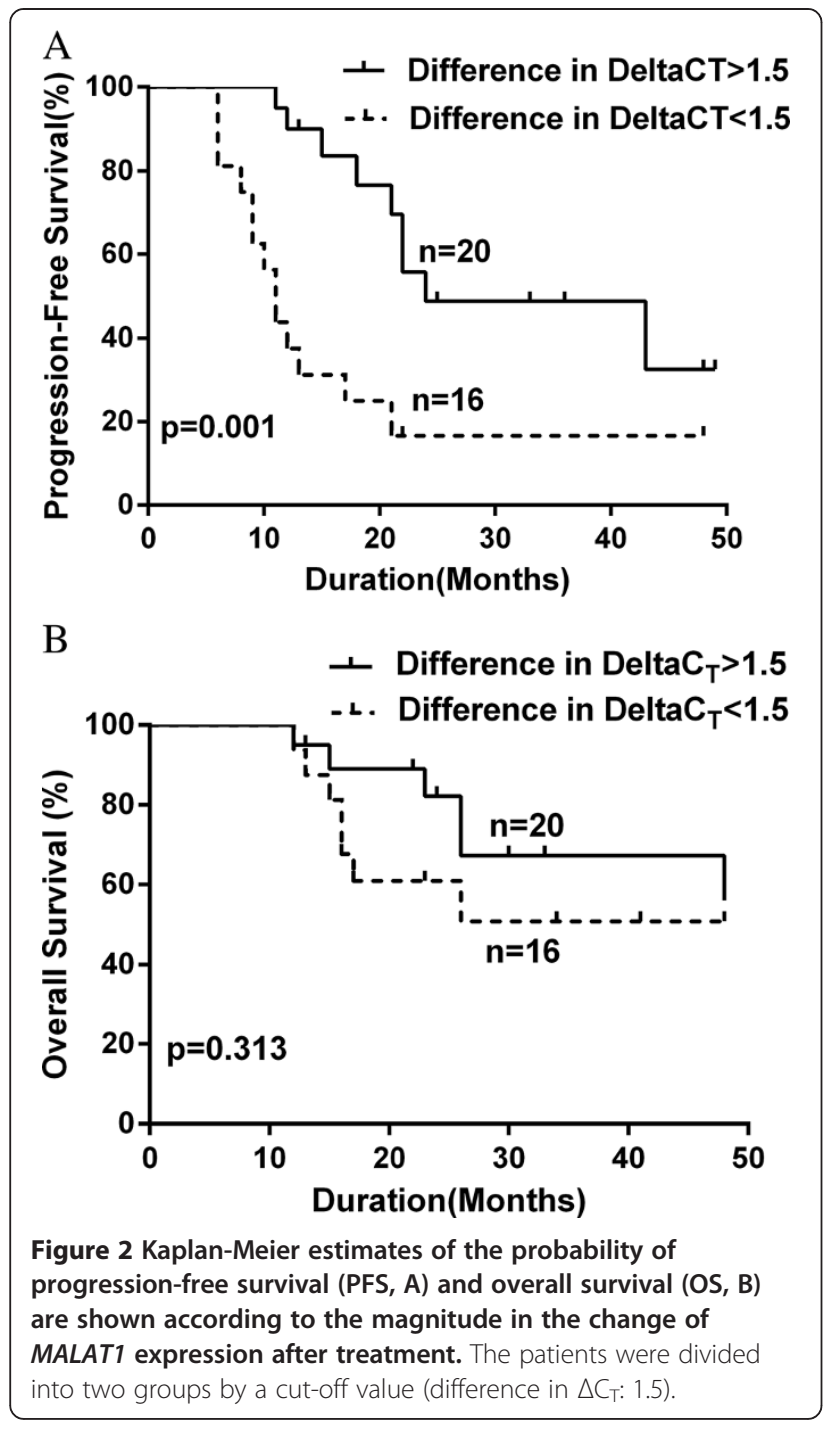

is related to poorer prognosis. We observed that the patients with a greater decrease in MALAT1 after initial treatment had a significantly prolonged PFS, which is consistent with the current consensus that therapeutic intervention to achieve a maximal response is beneficial for patients with multiple myeloma [31,32]. In terms of OS, we did not find a significant benefit in the post-treatment patients with a greater decrease in MALAT1. A possible explanation may be the incorporation of potent and effective salvage treatment in the patients who experienced a relapse or progression of disease, as well as the fact that some patients received auto-HSCT after salvage treatment.

We also found that MALAT1 may serve as a marker to predict early progression. Because the duration of response decreases with an increasing number of salvage regimens after progression, identification of patients at risk of early progression after first-line treatment is an important issue. More intensive treatment may improve the prognosis in this subgroup. We also found that patients with a smaller MALAT1 change after treatment had a significantly higher risk for early progression, even in those with a VGPR, CR and normal percentage of plasma cells in bone marrow. This finding suggests that the expression of MALAT1 can be used to identify the patients at risk of early progression. Accordingly, the therapeutic strategy may be adjusted to be initially more aggressive, as more potent treatment may reduce the risk of early progression and prolong PFS.

Our findings may provide a new insight into the pathogenesis of multiple myeloma. However, there are some limitations to this study. First, the cytogenetic examinations were done by conventional G-band metaphase chromosome analysis, and the percentage of cytogenetic abnormalities was relative low. Therefore, the association between MALAT1 and specific cytogenetic abnormalities remains to be determined. Further analysis by fluorescent in-situ hybridization with larger cohort may provide more impactful insight on the clinical relevance of MALAT1 expression in multiple myeloma. Second, we didn't evaluate the expression of MALAT1 in patients resistant to myeloma therapy due to no available samples. Third, the number of cases to evaluate the clinical relevance of MALAT1 was limited, which was likely due to the stringency of the enrollment criteria.

\section{Conclusions}

In conclusion, this study revealed that MALAT1 was overexpressed in patients with multiple myeloma, and

Table 3 Multivariate Cox regression analysis for all post-treatment patients and post-treatment patients with a treatment response of VGPR/CR

\begin{tabular}{|c|c|c|c|c|c|c|c|}
\hline & & & \multirow[t]{2}{*}{$\begin{array}{c}\text { PFS } \leq 18 \text { months } \\
\quad(N=18)\end{array}$} & \multirow[t]{2}{*}{$\begin{array}{l}\text { PFS >18 months } \\
\quad(\mathrm{N}=18)\end{array}$} & \multicolumn{3}{|c|}{$\begin{array}{l}\text { Cox regression } \\
\text { analysis }\end{array}$} \\
\hline & & & & & OR & $95 \% \mathrm{Cl}$ & $P$ value \\
\hline \multirow[t]{3}{*}{ All patients $(\mathrm{N}=36)$} & Auto-HSCT in 1 st line treatment, $\mathrm{n}$ & 9 & $2(11.1 \%)$ & 7(38.9\%) & 0.22 & $0.05-0.97$ & 0.046 \\
\hline & Difference in $\Delta C_{T} \leq 1.5, n$ & 17 & $13(72.2 \%)$ & $4(22.2 \%)$ & 4.89 & 1.73-13.86 & 0.003 \\
\hline & & & PFS $\leq 18$ months $(N=15)$ & PFS $>18$ months $(\mathrm{N}=18)$ & & & \\
\hline \multirow{2}{*}{$\begin{array}{l}\text { Patients with VGPR/CR } \\
(\mathrm{N}=33)\end{array}$} & Auto-HSCT in 1 st line treatment, $n$ & 9 & $2(13.3 \%)$ & $7(38.9 \%)$ & 0.24 & $0.05-1.09$ & 0.066 \\
\hline & Difference in $\Delta C_{T} \leq 1.5, n$ & 14 & $10(66.7 \%)$ & $4(22.2 \%)$ & 4.38 & $1.48-12.99$ & 0.008 \\
\hline
\end{tabular}

$\mathrm{OR}$, Odds ratio; $\mathrm{Cl}$, confidential interval; Auto-HSCT, autologous hematopoietic stem-cell transplantation; $\mathrm{CR}$, complete response; VGPR, very good partial response; PFS, progression-free survival. 
this IncRNA may play a role in the pathogenesis of the disease. In addition, the change in MALAT1 expression after treatment was clinically significant and may serve as a molecular predictor of the patients at risk of early progression of multiple myeloma.

\section{Additional files}

Additional file 1: Table S1. The clinical characteristics and expression of MALAT1 in 45 newly diagnosed patients with multiple myeloma.

Additional file 2: Table S2. Expression of MALAT1 and plasma cell percentage in the bone marrow in 45 newly diagnosed patients.

Additional file 3: Figure S1. Kaplan-Meier estimates of the probability of progression-free survival (PFS, 1A) and overall survival (OS, 1B) are based on the initial level of MALAT1 expression. The patients were divided into two groups by a cut-off value $\left(\triangle C_{T}:-5.30\right)$.

Additional file 4: Table S3. The clinical characteristics of the patients with different cut-off values.

\section{Competing interests}

The authors declare that they have no competing interest.

\section{Authors' contributions}

SFC, JGC and TCL designed the study. SFC, YCC, CSC, SFL, YCL, HHH, TCL contributed to collection and review of clinical data. SFC and YCC performed molecular examination. S-FC and CSC performed statistical analysis. SFC wrote the manuscript. SFC, TCL, JGC critically revised the manuscript. TCL and JGC approved the final version of the manuscript. All authors read and approved the final manuscript.

\section{Acknowledgments}

The authors thank the Statistical Analysis Laboratory, Department of Medical Research, Kaohsiung Medical University Hospital, Kaohsiung Medical University for their help.

\section{Author details}

${ }^{1}$ Graduate Institute of Clinical Medicine, College of Medicine, Kaohsiung Medical University, No.100, Shih-Chuan 1st Road, Kaohsiung 807, Taiwan. ${ }^{2}$ Division of Hematology \& Oncology, Department of Internal Medicine, Kaohsiung Medical University Hospital, Kaohsiung Medical University, No. 100, Tzyou 1st Road, Kaohsiung 807, Taiwan. ${ }^{3}$ Department of Laboratory Medicine, Kaohsiung Medical University Hospital, No. 100, Tzyou 1st Road, Kaohsiung 807, Taiwan. ${ }^{4}$ Graduate Institute of Healthcare Administration, Kaohsiung Medical University, No. 100, Shih-Chuan 1st Road, Kaohsiung 807, Taiwan. ${ }^{5}$ Faculty of Medicine, College of Medicine, Kaohsiung Medical University, No. 100, Shih-Chuan 1st Road, Kaohsiung 807, Taiwan. ${ }^{6}$ Epigenome Research Center, China Medical University Hospital, No. 2, Yuh-Der Road, Taichung 404, Taiwan. ${ }^{7}$ Department of Laboratory Medicine, China Medical University Hospital, No. 2, Yuh-Der Road, Taichung 404, Taiwan. ${ }^{8}$ School of Medicine, China Medical University, No.91, Hsueh-Shih Road, Taichung 404, Taiwan.

Received: 10 July 2014 Accepted: 23 October 2014 Published: 4 November 2014

\section{References}

1. Palumbo A, Anderson K: Multiple myeloma. N Engl J Med 2011, 364:1046-1060.

2. Weiss BM, Abadie J, Verma P, Howard RS, Kuehl WM: A monoclonal gammopathy precedes multiple myeloma in most patients. Blood 2009, 113:5418-5422.

3. Landgren O, Kyle RA, Pfeiffer RM, Katzmann JA, Caporaso NE, Hayes RB, Dispenzieri A, Kumar S, Clark RJ, Baris D, Hoover R, Rajkumar SV: Monoclonal gammopathy of undetermined significance (MGUS) consistently precedes multiple myeloma: a prospective study. Blood 2009, 113:5412-5417.
4. Kuehl WM, Bergsagel PL: Multiple myeloma: evolving genetic events and host interactions. Nat Rev Cancer 2002, 2:175-187.

5. Seidl S, Kaufmann H, Drach J: New insights into the pathophysiology of multiple myeloma. Lancet Oncol 2003, 4:557-564.

6. Bergsagel PL, Kuehl WM: Molecular pathogenesis and a consequent classification of multiple myeloma. J Clin Oncol 2005, 23:6333-6338.

7. Morgan GJ, Walker BA, Davies FE: The genetic architecture of multiple myeloma. Nat Rev Cancer 2012, 12:335-348.

8. Kumar S, Witzig TE, Timm M, Haug J, Wellik L, Fonseca R, Greipp PR, Rajkumar SV: Expression of VEGF and its receptors by myeloma cells. Leukemia 2003, 17:2025-2031.

9. Nefedova Y, Cheng P, Alsina M, Dalton WS, Gabrilovich DI: Involvement of Notch-1 signaling in bone marrow stroma-mediated de novo drug resistance of myeloma and other malignant lymphoid cell lines. Blood 2004, 103:3503-3510.

10. Hideshima $T$, Mitsiades $C$, Tonon G, Richardson PG, Anderson KC: Understanding multiple myeloma pathogenesis in the bone marrow to identify new therapeutic targets. Nat Rev Cancer 2007, 7:585-598.

11. Bertone P, Stolc V, Royce TE, Rozowsky JS, Urban AE, Zhu X, Rinn JL, Tongprasit W, Samanta M, Weissman S, Gerstein M, Snyder M: Global identification of human transcribed sequences with genome tiling arrays. Science 2004, 306:2242-2246.

12. International Human Genome Sequencing C: Finishing the euchromatic sequence of the human genome. Nature 2004, 431:931-945.

13. Hauptman N, Glavac D: Long non-coding RNA in cancer. Int J Mo/ SCi 2013, 14:4655-4669.

14. Ji P, Diederichs S, Wang W, Boing S, Metzger R, Schneider PM, Tidow N, Brandt B, Buerger H, Bulk E, Thomas M, Berdel WE, Serve H, Muller-Tidow C: MALAT-1, a novel noncoding RNA, and thymosin beta4 predict metastasis and survival in early-stage non-small cell lung cancer. Oncogene 2003, 22:8031-8041.

15. Guru SC, Agarwal SK, Manickam P, Olufemi SE, Crabtree JS, Weisemann JM, Kester MB, Kim YS, Wang Y, Emmert-Buck MR, Liotta LA, Spiegel AM, Boguski MS, Roe BA, Collins FS, Marx SJ, Burns L, Chandrasekharappa SC: A transcript map for the $2.8-\mathrm{Mb}$ region containing the multiple endocrine neoplasia type 1 locus. Genome Res 1997, 7:725-735.

16. van Asseldonk M, Schepens M, de Bruijn D, Janssen B, Merkx G, Geurts van Kessel A: Construction of a 350-kb sequence-ready 11 q13 cosmid contig encompassing the markers D11S4933 and D11S546: mapping of 11 genes and 3 tumor-associated translocation breakpoints. Genomics 2000, 66:35-42.

17. Wilusz JE, Freier SM, Spector DL: $3^{\prime}$ end processing of a long nuclear-retained noncoding RNA yields a tRNA-like cytoplasmic RNA. Cell 2008, 135:919-932.

18. Friedel CC, Dolken L, Ruzsics Z, Koszinowski UH, Zimmer R: Conserved principles of mammalian transcriptional regulation revealed by RNA half-life. Nucleic Acids Res 2009, 37:e115.

19. Hutchinson JN, Ensminger AW, Clemson CM, Lynch CR, Lawrence JB, Chess A: A screen for nuclear transcripts identifies two linked noncoding RNAs associated with SC35 splicing domains. BMC Genomics 2007, 8:39.

20. Miyagawa R, Tano K, Mizuno R, Nakamura Y, ljiri K, Rakwal R, Shibato J, Masuo Y, Mayeda A, Hirose T, Akimitsu N: Identification of cis- and trans-acting factors involved in the localization of MALAT-1 noncoding RNA to nuclear speckles. RNA 2012, 18:738-751.

21. Tripathi V, Ellis JD, Shen Z, Song DY, Pan Q, Watt AT, Freier SM, Bennett CF, Sharma A, Bubulya PA, Blencowe BJ, Prasanth SG, Prasanth KV: The nuclear-retained noncoding RNA MALAT1 regulates alternative splicing by modulating SR splicing factor phosphorylation. Mol Cell 2010, 39:925-938.

22. Yang F, Yi F, Han X, Du Q, Liang Z: MALAT-1 interacts with hnRNP C in cell cycle regulation. FEBS Lett 2013, 587:3175-3181.

23. Tripathi V, Shen Z, Chakraborty A, Giri S, Freier SM, Wu X, Zhang Y, Gorospe M, Prasanth SG, Lal A, Prasanth KV: Long noncoding RNA MALAT1 controls cell cycle progression by regulating the expression of oncogenic transcription factor B-MYB. PLoS Genet 2013, 9:e1003368.

24. Schmidt LH, Spieker T, Koschmieder S, Schaffers S, Humberg J, Jungen D, Bulk E, Hascher A, Wittmer D, Marra A, Hillejan L, Wiebe K, Berdel WE, Wiewrodt R, Muller-Tidow C: The long noncoding MALAT-1 RNA indicates a poor prognosis in non-small cell lung cancer and induces migration and tumor growth. J Thorac Oncol 2011, 6:1984-1992.

25. Xu C, Yang M, Tian J, Wang X, Li Z: MALAT-1: a long non-coding RNA and its important 3 ' end functional motif in colorectal cancer metastasis. Int $J$ Oncol 2011, 39:169-175. 
26. Ying L, Chen Q, Wang Y, Zhou Z, Huang Y, Qiu F: Upregulated MALAT-1 contributes to bladder cancer cell migration by inducing epithelial-tomesenchymal transition. Mol Biosyst 2012, 8:2289-2294.

27. Gutschner T, Hammerle M, Eissmann M, Hsu J, Kim Y, Hung G, Revenko A, Arun G, Stentrup M, Gross M, Zornig M, MacLeod AR, Spector DL,

Diederichs S: The noncoding RNA MALAT1 is a critical regulator of the metastasis phenotype of lung cancer cells. Cancer Res 2013, 73:1180-1189

28. Lane L, Argoud-Puy G, Britan A, Cusin I, Duek PD, Evalet O, Gateau A, Gaudet P, Gleizes A, Masselot A, Zwahlen C, Bairoch A: neXtProt: a knowledge platform for human proteins. Nucleic Acids Res 2012, 40:D76-83.

29. Wu C, Macleod I, Su Al: BioGPS and MyGene.info: organizing online, gene-centric information. Nucleic Acids Res 2013, 41:D561-565.

30. Isin M, Ozgur E, Cetin G, Erten N, Aktan M, Gezer U, Dalay N: Investigation of circulating IncRNAs in B-cell neoplasms. Clin Chim Acta 2014, 431:255-259.

31. Chanan-Khan AA, Giralt S: Importance of achieving a complete response in multiple myeloma, and the impact of novel agents. J Clin Oncol 2010, 28:2612-2624

32. Moreau P, Attal M, Pegourie B, Planche L, Hulin C, Facon T, Stoppa AM, Fuzibet JG, Grosbois B, Doyen C, Ketterer N, Sebban C, Kolb B, Chaleteix C, Dib M, Voillat L, Fontan J, Garderet L, Jaubert J, Mathiot C, Esseltine D, Avet-Loiseau H, Harousseau JL, investigators IFMs: Achievement of VGPR to induction therapy is an important prognostic factor for longer PFS in the IFM 2005-01 trial. Blood 2011, 117:3041-3044.

doi:10.1186/1471-2407-14-809

Cite this article as: Cho et al: MALAT1 long non-coding RNA is overexpressed in multiple myeloma and may serve as a marker to predict disease progression. BMC Cancer 2014 14:809.

\section{Submit your next manuscript to BioMed Central and take full advantage of:}

- Convenient online submission

- Thorough peer review

- No space constraints or color figure charges

- Immediate publication on acceptance

- Inclusion in PubMed, CAS, Scopus and Google Scholar

- Research which is freely available for redistribution 